\title{
Oxidative Stress Parameters as Markers of the different Trimesters in Normal Pregnancy
}

\section{${ }^{1}$ OGHAGBON, SE; ${ }^{1}{ }^{1}$ AGU, KC; ${ }^{1}$ OMOROWA, FE; ${ }^{2}$ OKOLIE, NP; ${ }^{1}$ OKWUMABUA, M; ${ }^{1}$ OMO-ERHABOR, JA}

\author{
${ }^{1}$ Department of Medical Biochemistry, School of Basic Medical Sciences, \\ College of Medical Sciences, University of Benin \\ ${ }^{2}$ Departments of Biochemistry, Faculty of Life Sciences, University of Benin \\ *Corresponding author e-mail: chukwunonso.agu@uniben.edu; Phone: 08035657035
}

\begin{abstract}
Pregnancy has been associated with changes in physiologic and metabolic functions accompanied by a high metabolic demand and elevated requirements for tissue oxygen with eventual increase in oxidative pressure on the antioxidant defence system of the body. Thus, it was based on this premise that some markers of pro-oxidant- antioxidant status of pregnancy compared with non-pregnant state were assessed including, marker of lipid peroxidation (malondialdehyde, MDA), superoxide dismutase (SOD), catalase (CAT) and glutathione peroxidise (GPx). A total of 41 apparently healthy female volunteers were used for this study made up of 36 pregnant females at different trimester of pregnancy, categorised into three (3) groups of 12 each per trimester, and whose ages ranged between 19 years and 40 years. Standard biochemical assays were employed in the assessment of these markers. The level of lipid peroxidation $(\mathrm{MDA})$ increased progressively for the pregnant subjects $(\mathrm{p}<0.05)$ at the third trimester $(18.2 \mathrm{mmole} / \mathrm{ml})$ compared to the non-pregnant controls $(2.3 \mathrm{mmole} / \mathrm{ml})$; an increase in SOD activity was also observed $(\mathrm{p}<0.05)$ at the third trimester $(8.9 \mathrm{U} / \mathrm{ml})$ compared to the control $(6.3 \mathrm{U} / \mathrm{ml})$ contrary to some other researches; while decrease in CAT $(9.2 \mathrm{U} / \mathrm{ml})$ and GPx $(7.8 \mathrm{U} / \mathrm{ml})$ activities at the third trimester compared to the non-pregnant control $(\mathrm{p}<0.05)$ (307.5U/ml and $9.4 \mathrm{U} / \mathrm{ml}$, respectively) were also observed. There was an observed increase in the body mass index, BMI, from first trimester, $26.4 \mathrm{~kg} / \mathrm{m}^{2}$ and second trimester, $38.4 \mathrm{~kg} / \mathrm{m}^{2}$ to the third trimester, $42.7 \mathrm{~kg} / \mathrm{m}^{2}$, compared to the control, $33.7 \mathrm{~kg} / \mathrm{m}^{2}$ supporting the claims that pathologic conditions associated with pregnancy become more prominent with increase in BMI. Thus, these biochemical markers of oxidative stress, viz., superoxide dismutase (SOD), catalase (CAT), glutathione peroxidase (GPx) and malondialdehyde (MDA) can serve as markers to assess the stages of pregnancy and also can be used to differentiate pathologic and nonpathologic pregnant conditions. OJASEM

http://dx.doi.org/10.4314/iasem.v20i3.10
\end{abstract}

Key words- Antioxidants; Pregnancy; Pro-oxidants; Trimesters; Free radicals; Body mass index

Many free radicals are produced in the body as a result of a myriad of biochemical processes taking place in normal metabolism (Du et al., 2003). An imbalance between reactive oxygen species and antioxidant defence mechanism of a cell leads to an excessive production of oxygen metabolites, creating a condition known as oxidative stress (Sudha et al., 2001). Pregnancy has been known to be associated with alteration in physiological and metabolic functions (Qanungo and Mukherjea, 2000). According to Knapene et al. (1999), Idonije et al (2011) and Okojie et al. (2011), pregnancy is accompanied by a high metabolic demand and elevated requirements for tissue oxygen which results in increased oxidative pressure on the antioxidant defence system. These challenges undoubtedly are imposed by the physiologic and biochemical demands of the growing foetus. Maternal hormonal changes could also be implicated as secondary initiators. Pregnancy imposes a heavy demand on metabolic energy, leading to an elevation in maternal basal metabolic rate (BMR) (Idonoje et al., 2011). To meet this increased energy requirement during pregnancy, the human placenta is highly vascularised and sufficiently exposed to high maternal oxygen partial pressure (Agarwal et al., 2005). It has been reported that intrauterine oxygen partial pressure increases progressively throughout pregnancy and is paralleled by proportionate rise in activities of the major antioxidant enzymes (Jauniaux et al., 1999, 2000, 2003 and 2006). Thus, this research was based on support the claim that oxidative stress and antioxidant enzyme activities increase progressively with pregnancy (compared to the non-pregnant state), and establish a base-line biochemical argument that some of these oxidative stress parameters can serve as markers for the various stages of pregnancy. Thus, this research was aimed at establishing whether these biochemical markers of oxidative stress, viz., superoxide dismutase (SOD), catalase (CAT), glutathione peroxidase (GPx) and malondialdehyde (MDA) could serve as markers in the assessment of the stages of pregnancy and also if they can be used 
to differentiate pathologic and non-pathologic pregnant conditions.

Some of the markers that were assessed included, the marker of lipid peroxidation (malondialdehyde, MDA), superoxide dismutase (SOD), catalase (CAT) and glutathione peroxidise (GPx).

\section{MATERIALS AND METHODS}

Subjects: A total of 41 apparently healthy female volunteers were used for this study. This was made up of 36 pregnant females at different trimester of pregnancy, categorised into three (3) groups of 12 each per trimester, and whose ages ranged between 19 years and 40 years. These were attending antenatal clinic at Egbe clinic and maternity in Benin City metropolis. Controls were five (5) healthy nonpregnant women, whose non-pregnant status was determined using Human chorionic gonadotropin (HCG) rapid pregnancy determination strips. Subjects were medically certified by assessing their health status and those with obesity, diabetes mellitus under medication and untreated diabetes, alcoholics, severely anaemic and those suffering from any other systemic disorder were excluded from the study. Ethical clearance was obtained.

\section{RESULTS AND DISCUSSION}

Table 1: Level of lipid peroxidation and antioxidant status of subjects

\begin{tabular}{lllll}
\hline Groups & $\begin{array}{l}\text { MDA } \\
(\mathbf{m m o l} . / \mathbf{m l})\end{array}$ & $\begin{array}{l}\text { SOD } \\
(\mathbf{U} / \mathbf{m l})\end{array}$ & $\begin{array}{l}\text { CAT } \\
(\mathbf{U} / \mathbf{m l})\end{array}$ & $\begin{array}{l}\mathbf{G P X} \\
(\mathbf{U} / \mathbf{m l})\end{array}$ \\
\hline control & $2.27 \pm 0.20^{\mathrm{a}}$ & $6.34 \pm 0.20^{\mathrm{a}}$ & $307.49 \pm 34.00^{\mathrm{a}}$ & $9.43 \pm 0.10^{\mathrm{a}}$ \\
$\mathbf{1}^{\text {st }}$ trimester & $7.25 \pm 0.70^{\mathrm{bc}}$ & $6.72 \pm 0.60^{\mathrm{ac}}$ & $21.39 \pm 3.00^{\mathrm{bc}}$ & $8.78 \pm 0.50^{\mathrm{bc}}$ \\
$\mathbf{2}^{\text {nd }}$ trimester & $13.77 \pm 2.00^{\mathrm{bdf}}$ & $7.43 \pm 0.30^{\mathrm{bce}}$ & $13.50 \pm 2.00^{\mathrm{bcd}}$ & $7.91 \pm 0.30^{\mathrm{bcd}}$ \\
$\mathbf{3}^{\text {rd }}$ trimester & $18.22 \pm 1.00^{\mathrm{bef}}$ & $8.90 \pm 0.20^{\mathrm{bdf}}$ & $9.15 \pm 0.20^{\mathrm{bce}}$ & $7.84 \pm 0.30^{\mathrm{bcd}}$ \\
\hline
\end{tabular}

Values are represented as mean \pm SEM. Values with different superscripts per parameter down the groups indicate significant difference $(\mathrm{p}<0.05)$.

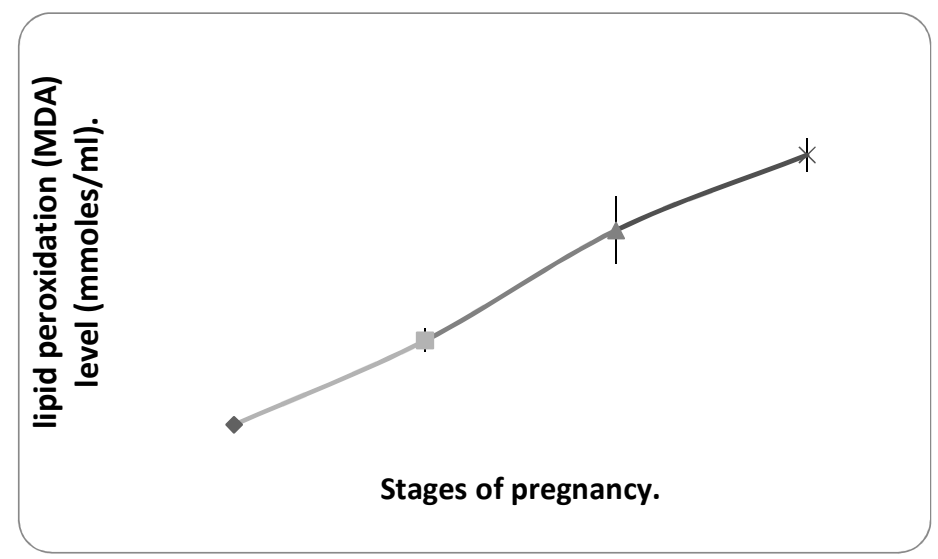

Fig 1: Lipid peroxidation (MDA) level in the various trimesters of pregnant Subjects compared to the non-pregnant control group.
Sample collection and preparation: Lithium heparin and plain specimen bottles were used for each test and control subjects. $10 \mathrm{ml}$ blood samples were collected by venipuncture from the ante-cubital fossa into heparinised bottles. The blood was then centrifuged at $400 \mathrm{~g}$ for $15 \mathrm{mins}$. The plasma was by using Pasteur pipette, transferred to plain bottles and stored in the freezing compartment before analyses.

Assay of samples: Malondialdehyde (MDA) level was estimated using method described by Marklund and Marklund (1974); Superoxide dismutase (SOD) ctivity was assayed using the method described by and Fridovich (1972); catalase activity (CAT) was assayed using the method described by Cohen et al. (1970); while glutathione peroxidise (GPx) activity was assayed using the method described by Tappel (1978).

Statistical analysis: All data were expressed as mean \pm standard error of mean (SEM) and analysed using the paired sample T-test of the statistical package for social sciences (SPSS) version 16, at a p-value of 0.05. Table 1: Plasma antioxidant enzyme activities (units/ml) and lipid peroxidation (MDA) level (mmoles/ml). 


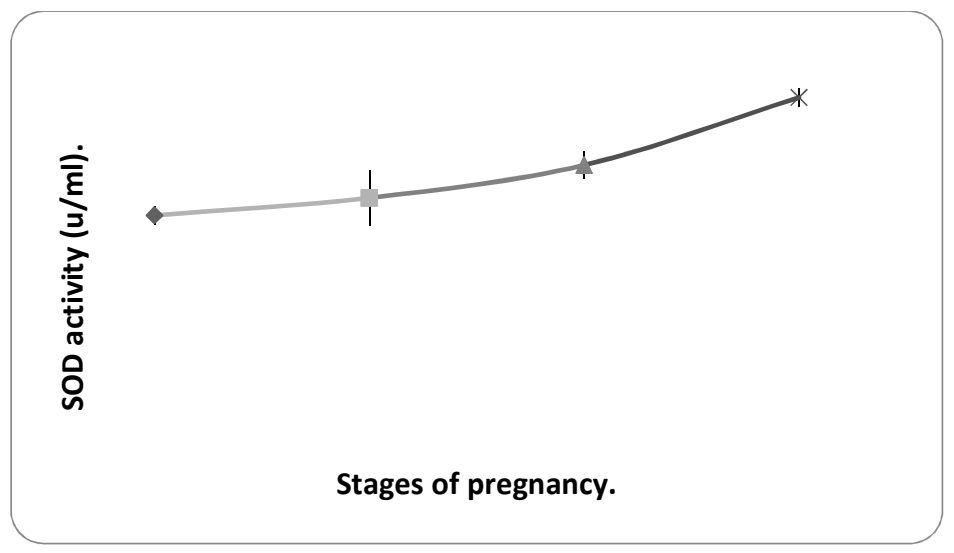

Fig 2: Superoxide dismutase activity in the various trimesters of pregnant subjects compared to the non-pregnant control group.

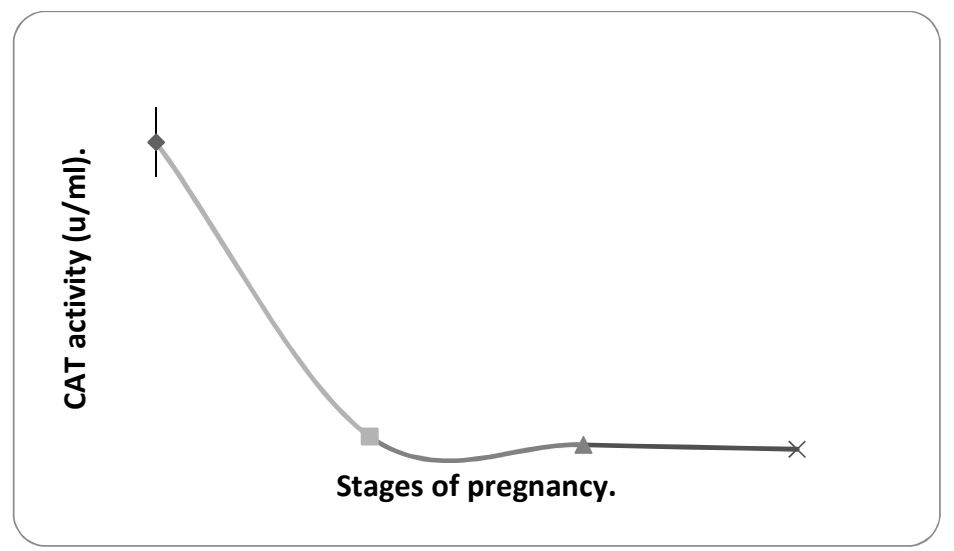

Fig 3: Catalase activity in the various trimesters of pregnant subjects compared to the non-pregnant control group.

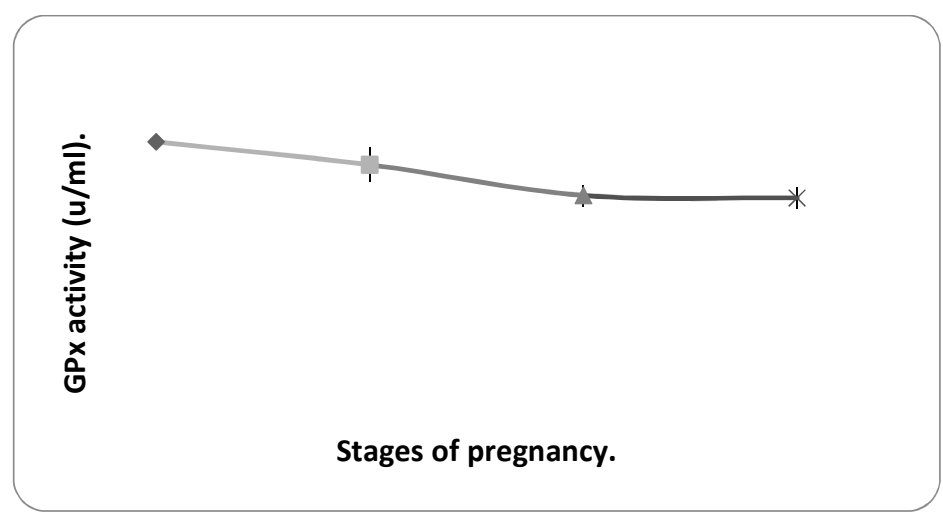

Fig 4: Glutathione peroxidase activity in the various trimesters of pregnant subjects compared to the nonpregnant control group.

Table 2: Some anthropometric data and body mass index (BMI) of the subjects

\begin{tabular}{lllll}
\hline Groups & $\begin{array}{l}\text { Age } \\
(\text { years })\end{array}$ & $\begin{array}{l}\text { Weight } \\
(\mathrm{Kg})\end{array}$ & $\begin{array}{l}\text { Height } \\
(\mathrm{cm})\end{array}$ & $\begin{array}{l}\text { BMI } \\
\left(\mathrm{Kg} / \mathrm{m}^{2}\right)\end{array}$ \\
\hline control & $26 \pm 0.00^{\mathrm{a}}$ & $62.40 \pm 0.00^{\mathrm{a}}$ & $136 \pm 0.00^{\mathrm{a}}$ & $33.74 \pm 0.20^{\mathrm{a}}$ \\
$1^{\text {st }}$ trimester & $28 \pm 0.00^{\mathrm{b}}$ & $66.80 \pm 0.00^{\mathrm{b}}$ & $159 \pm 0.01^{\mathrm{b}}$ & $26.42 \pm 0.90^{\mathrm{b}}$ \\
$2^{\text {nd }}$ trimester & $29 \pm 0.01^{\mathrm{b}}$ & $77.40 \pm 0.00^{\mathrm{c}}$ & $142 \pm 0.00^{\mathrm{c}}$ & $38.39 \pm 0.00^{\mathrm{c}}$ \\
$3^{\text {rd }}$ trimester & $29 \pm 0.00^{\mathrm{b}}$ & $81.30 \pm 0.10^{\mathrm{d}}$ & $138 \pm 0.00^{\mathrm{d}}$ & $42.69 \pm 0.02^{\mathrm{d}}$ \\
\hline
\end{tabular}

Values are represented as mean \pm SEM. Values with different

superscripts per parameter down the groups indicate significant difference $(\mathrm{p}<0.05)$. 
Knapen et al. (1999) had stated that pregnancy is accompanied by a high metabolic demand and elevated requirements for tissue oxygen, thus resulting in increased oxidative stress and a corresponding antioxidant enzyme turnover. This was evident in this present research as we sort to establish that some of these markers of oxidative stress could be used to assess the progress of the various stages of pregnancy in normal females. The level of lipid peroxidation (MDA) increased progressively $(\mathrm{p}<0.05)$ compared to the controls (Iioka, 1994). During gestation, elevations in products of lipid peroxidation appear by the second trimester and may taper off later in gestation, decreasing further after delivery. Lipid peroxides also are produced in placenta, but their pattern of change over the course of pregnancy is unclear. Lipid peroxides are important because their uncontrolled production can result in oxidative stress, with significant damage to cell integrity (Little and Gladen, 1999). An increase in SOD activity was also observed $(\mathrm{p}<0.05)$ which is contrary to some other researches. Patil et al. (2006) reported a decrease in antioxidant enzymes, where they argued that it probably could be due to a compensatory response to the increased lipid peroxide load in some forms of pathologic conditions (preeclamptic and eclamptic patients). However, in the present research, non-pathologic pregnant subject were used thus suggesting that SOD could be the major antioxidant defence against oxidative stress in pregnancy with a pathologic condition. Decrease in CAT (from $21 \mathrm{U} / \mathrm{ml}$ of first trimester, further to $9 \mathrm{U} / \mathrm{ml}$ of the third trimester) and GPx (from $8.8 \mathrm{U} / \mathrm{ml}$ of first trimester to $7.8 \mathrm{U} / \mathrm{ml}$ of the third trimester) activities compared to the non-pregnant control $(307 \mathrm{U} / \mathrm{ml}$ and $9.4 \mathrm{U} / \mathrm{ml}$, respectively) $(\mathrm{p}<0.05)$ were also observed. These agree with reported literature levels of these enzymes suggesting increased turn-over of these enzymes due to oxidative burden arising from increased production of lipid peroxides.

However, the body mass index reflected in table 2 demonstrated a steady increase from first trimester, $26.4 \mathrm{~kg} / \mathrm{m}^{2}$ and second trimester, $38.4 \mathrm{~kg} / \mathrm{m}^{2}$ to the third trimester, $42.7 \mathrm{~kg} / \mathrm{m}^{2}$, compared to the control, $33.7 \mathrm{~kg} / \mathrm{m}^{2}$. Yazdani et al. (2012) had reported that maternal obesity has been associated with adverse pregnancy outcomes, such as pre-eclampsia, eclampsia, pre- and post-term delivery, induction of labor, macrosomia, increased rate of caesarean section, and post-partum hemorrhage. According to their findings, increased BMI increased the incidence of induction of labor, caesarean section, pre-term labor and macrosomia. The BMI of women in the first trimester of pregnancy is associated with the risk of adverse pregnancy outcome. Thus, the observed increase in BMI with pregnancy in this research points to possible occurrence of these pathologic conditions in the subjects used as well as, concurrent over-whelm of the anti-oxidant defence.

Conclusion: These biochemical markers of oxidative stress, viz., superoxide dismutase (SOD), catalase (CAT), glutathione peroxidase (GPx) and malondialdehyde (MDA) can be used to assess the stages of pregnancy and also can be used to differentiate pathologic and non-pathologic pregnant conditions. Also, the observed decrease in the antioxidant enzyme defence (CAT and GPx) with a disproportionately increasing MDA levels is a clear indication of the negative effect of BMI increase in pregnancy. This supports the claims about the health compromise of pregnant women when BMI is not properly monitored.

Acknowledgement: We hereby acknowledge the Department of Medical Biochemistry, School of Basic Medical Sciences, College of Medical Sciences, University of Benin for the providing the laboratory space during the course of the research.

\section{REFERENCES}

Agarwal, A; Gupta, S; Sharma, KR (2005). Role of oxidative stress in female reproduction. Reproductive Biology and Endocrinology 3: 28.

Cohen, G; Dembiec, D; Marcus, J (1970). Measurement of catalase activity in tissue extracts. Ann. Biochem. 34: 30-38.

Du, WD; Yuan, ZR; Sun, J; Tang, JX; Cheng, AQ; Shen, DM; Song, XH; Yu, XF; Zheng, SB (2003). Therapeutic efficacy of high dose vitamin $\mathrm{C}$ on acute pancreatitis and its potential mechanisms. World J Gastroenterol. 11: 25652569.

Idonije, OB; Festus, O; Okhiai, O; Akpamu, U (2011) A Comparative Study of the Status of Oxidative Stress in Pregnant Nigerian Women. Research Journal of Obstetrics and Gynecology 4: 28-36.

Iioka, H (1994). Changes in blood level of lipid peroxide and vitamin $\mathrm{E}$ during pregnancy: clinical significance and relation to the pathogenesis of EPH gestosis. Gynecol Obstet Invest. 38(3): 173-176.

Jauniaux, E; Hempstock, J; Greenwold, N; Burton, GJ (2003) Trophoblastic oxidative stress in relation to temporal and regional differences in maternal placental blood flow in normal and abnormal early pregnancies. American Journal of Pathology 162: 115-125.

Jauniaux, E; Poston, L;Burton, GJ (2006). Placentalrelated diseases of pregnancy: Involvement of 
oxidative stress and implications in human evolution. Human Reproduction Update 12: 747-755.

Jauniaux, E; Watson, A; Burton, G (2001).Evaluation of respiratory gases and acid-base gradients in human fetal fluids and uteroplacental tissue between 7 and 16 weeks' gestation. American Journal of Obstetrics and Gynecology 184: 9981003.

Jauniaux, E; Watson, A; Ozturk, O; Quick, D; Burton, $\mathrm{G}$ (1999). In vivo measurement of intrauterine gases and acid-base values early in human pregnancy. Hum. Reprod. 14: 2901-2904.

Knapen, MFCM; Zusterzeel, PLM; Peters, WHM; Steegers, EAP (1999). Glutathione and glutathione-related enzymes in reproduction: A review. Eur. J. Obstetrics Gynecol. Reprod. Biol. 82: 171-184.

Little, RE; Gladen, BC (1999). Levels of lipid peroxides in uncomplicated pregnancy: a review of the literature. Reprod. Toxicol. 13(5): 347352.

Marklund, S; Marklund, G (1974). Involvement of the superoxide anion radical in the autoxidation of pyrogallol and a convenient assay for superoxide dismutase. European Journal of Biochemistry 47: 469-474.

Misra, HP; Fridovich, I (1972). The Role of Superoxide Anion in the Autoxidation of Epinephrine and a Simple Assay for Superoxide Dismutase. The Journal of Biological Chemistry 247: 3170-3175.
Okojie, FO; Idonije, OB; Eseigbe, MA; Okhiai, O; Unuabonah, F; Dike, M (2011). Comparative study of lipid profile of normal pregnant women in the different trimesters. Achives of Applied Science Research 3(3): 528-532.

Patil, SB; Kodliwadmath, MV; Kodliwadmath, M (2009). Lipid peroxidation and antioxidant activity in complicated pregnancies. Clin. Exp. Obstet. Gynecol. 36(2):110-112.

Qanungo, S; Sen, A; Mukherjea, M (1999). Antioxidant status and lipid peroxidation in human feto-placental unit. Clinical Chemical Acta 285: 1-12.

Sudha, K; Rao, AV; Rao, A (2001). Oxidative stress and antioxidants in epilepsy. Clinical Chemical Acta 303(1-2): 19-24.

Tappel, AL (1978). Glutathione peroxidase and hydroperoxidase. Methods in Enzymol. 52: 506513.

Yazdani, $\quad$ S; Yosofniyapasha, $\quad$ Y; Nasab, $\quad$ BH; Mojaveri, MH; Bouzari, Z (2012). Effect of maternal body mass index on pregnancy outcome and newborn weight. BMC Res Notes. 5: 34. 